\title{
Morphophysiology of yellow passion fruit seedlings under application of nitrogen and potassium and irrigation with high- salinity water
}

\section{Morfofisiologia de mudas de maracujazeiro amarelo sob aplicação de nitrogênio e potássio e irrigadas com águas salinas}

\author{
Francisco Romário Andrade Figueiredo ${ }^{1 *}$; Jackson Silva Nóbrega ${ }^{2}$; \\ Reynaldo Teodoro de Fátima ${ }^{3}$; Jean Telvio Andrade Ferreira ${ }^{4}$; \\ Micaela Benigna Pereira²; Maria de Fátima de Queiroz Lopes²; \\ Walter Esfrain Pereira ${ }^{5}$; Manoel Bandeira de Albuquerque ${ }^{5}$
}

\section{Highlights:}

Salinity seriously damages the physiology and growth of yellow passion fruit seedlings.

The foliar application of $\mathrm{N}$ improves the plant growth and physiology.

The foliar application of $\mathrm{N}$ and $\mathrm{K}$ attenuates the damage of salinity to yellow passion fruit seedlings.

\begin{abstract}
Salinity is one of the most problematic abiotic stresses in agriculture globally, especially in semi-arid regions. Thus, the application of nutrients, such as nitrogen and potassium to improve plant nutritional conditions may be a viable alternative to minimize the negative effects of saline stress. Therefore, the aim of this study was to evaluate the morphophysiological behavior of yellow passion fruit seedlings under varying nitrogen and potassium doses and irrigation with salt water. The experimental design was a randomized complete block with a $5 \mathrm{x} 5$ incomplete factorial scheme, generated from the Central Composite Design with five electrical conductivities of irrigation water $(0.5,0.98,2.15,3.32$, and 3. 80 $\left.\mathrm{dS} \mathrm{m}^{-1}\right)$ and five increasing doses of nitrogen and potassium $(0.0,29.08,100.0,170.92$, and 200.0\%). Leaf, stem, and root dry phytomass and gas exchange were evaluated 75 days after sowing. The increase in salinity had negative effects on the morphological and physiological characteristics of yellow passion fruit seedlings. The application of nitrogen and potassium positively influenced photosynthetic rate and leaf and root dry phytomasses. The application of nitrogen and potassium increased intercellular $\mathrm{CO}_{2}$ concentration and transpiration in yellow passion fruit seedlings under saline stress.
\end{abstract}

Key words: Passiflora edulis. Gas exchange. Saline stress.

1 Discente do Curso de Doutorado do Programa de Pós-Graduação em Fitotecnia, Universidade Federal Rural do Semi-Árido, UFERSA, Mossoró, RN, Brasil. E-mail: romarioagroecologia@yahoo.com.br

2 Discentes do Curso de Doutorado do Programa de Pós-Graduação em Agronomia, Universidade Federal da Paraíba, UFPB, Areia, PB, Brasil. E-mail: jacksonnobrega@hotmail.com; micaelle.bp@gmail.com; fatimaqueiroz0@gmail.com

3 Discente do Curso de Doutorado do Programa de Pós-Graduação em Engenharia Agrícola, Universidade Federal de Campina Grande, UFCG, Campina Grande, PB, Brasil. E-mail: reynaldo.t16@gmail.com

4 M.e, Programa de Pós-Graduação em Agronomia, UFPB, Areia, PB, Brasil. E-mail: jeantelvioagronomo@gmail.com

5 Profs. Drs., Programa de Pós-Graduação em Agronomia, UFPB, Areia, PB, Brasil. E-mail: walterufpb@yahoo.com.br; bandeira1977@gmail.com

* Author for correspondence 


\section{Resumo}

A salinidade é um dos estresses abióticos mais preocupantes na agricultura mundial, principalmente nas regiões semiáridas. Assim, a aplicação de nutrientes como nitrogênio e o potássio visando melhorar as condições nutricionais das plantas pode ser uma alternativa viável para minimizar os efeitos negativos do estresse salino. Portanto, objetivou-se avaliar o comportamento morfofisiológico de mudas de maracujazeiro-amarelo sob doses de nitrogênio e potássio e irrigadas com águas salinas. $\mathrm{O}$ delineamento utilizado foi em blocos casualizados, em esquema fatorial incompleto $5 \times 5$, gerados a partir da matriz Composto Central de Box com cinco condutividades elétricas da água de irrigação $(0,5$; 0,$98 ; 2,15 ; 3,32$ e $\left.3,80 \mathrm{dS} \mathrm{m}^{-1}\right)$ e cinco doses crescentes de nitrogênio e potássio $(0,0 ; 29,08 ; 100,0$; $170,92$ e $200,0 \%)$. Foram avaliadas as fitomassas seca de folha, caule e raiz e as trocas gasosas aos 75 dias após a semeadura. $\mathrm{O}$ aumento da salinidade proporciona efeitos negativos nas características morfofisiológicas do maracujazeiro amarelo. A aplicação de nitrogênio e potássio influencia positivamente na taxa fotossintética e fitomassa seca das folhas e raiz. A aplicação de nitrogênio e potássio aumenta concentração intercelular de $\mathrm{CO}_{2}$ e transpiração de mudas de maracujazeiro-amarelo sob estresse salino.

Palavras-chave: Passiflora edulis. Trocas gasosas. Estresse salino.

\section{Introduction}

The yellow passion fruit (Passiflora edulis Sims. f. flavicarpa) is the most recognized and cultivated Passifloraceae species in Brazil (Figueiredo, Hafle, Rodrigues, Pereira, \& Delfino, 2015). In the Brazilian semi-arid region, the management of this crop is dependent on irrigation, which most often involves the use of highly saline water (Cavalcante, Dias, Nascimento, \& Freire, 2011). The salinity of both irrigation water and soil is one of the abiotic stresses that limits plant growth, development, and productivity, worldwide (Freire, Dias, Cavalcante, Fernandes, \& Lima, 2014).

In this sense, the increase in soluble salts in the soil reduces its osmotic potential and decreases water and nutrient uptake by plants (Araújo et al., 2016). As a consequence, there is a decrease in growth and leaf expansion, which induces stomatal closure and results in inhibition of the photosynthetic rate (Taiz, Zeiger, Moller, \& Murphy, 2017). The excessive accumulation of toxic ions such as chlorine $(\mathrm{Cl})$ and sodium $\left(\mathrm{Na}^{+}\right)$causes nutritional imbalance, due to the lower availability, absorption and transport of nitrogen $(\mathrm{N})$ and potassium $(\mathrm{K})$, two essential macronutrients for the physiological and biochemical processes of plants (M. A. F. Bezerra et al., 2019).
In this context, complementing fertilization with these nutrients $(\mathrm{N}$ and $\mathrm{K}$ ) considered limiting in saline soils can be a viable alternative, since mineral nutrition is an important environmental factor. Nitrogen is one of the nutrients most required by plants, due to its structural function and being part of several organic compounds, leading to a greater capacity for osmotic adjustment when plants are subjected to abiotic stresses, such as saline and water stresses (Oliveira et al., 2014). Potassium, on the other hand, participates in several metabolic processes transport protein and enzymatic activation and is involved in the stoma opening and closing mechanism and $\mathrm{CO}_{2}$ assimilation capacity (Almeida, Pancelli, Prado, Cavalcante, \& Cruz, 2015).

Thus, the production of quality seedlings is of great importance for the establishment of culture in the field, especially in salinized areas, because salinity alters the hormonal balance, increases the production of reactive oxygen species, influences growth, and decreases the quality of seedlings (M. A. F. Bezerra et al., 2019). Therefore, the objective of this study was to evaluate the morphophysiological behavior of yellow passion fruit seedlings under increasing salinity levels of irrigation water and varying doses of nitrogen and potassium. 


\section{Material and Methods}

The experiment was conducted from April to June 2018, in a greenhouse at the Centro de Ciências Agrárias, Universidade Federal da Paraíba, municipality of Areia, Paraíba, Brazil. The municipality is located at the geographical coordinates $6^{\circ} 58^{\prime} 00^{\prime \prime} \mathrm{S}$ and $35^{\circ} 41^{\prime} 00^{\prime \prime} \mathrm{W}$ at an altitude of $575 \mathrm{~m}$. The climate of the region, according to the Köppen classification, is As' type, which means dry and hot summer and rainy winter (Alvares, Stape, Sentelhas, Gonçalves, \& Sparovek, 2013). The experimental design used was randomized blocks with four replications and two plants per plot. The treatments were obtained through the Central Composite Design (Mateus, Barbin, \& Conagin, 2001) with five electrical conductivities of irrigation water (ECiw) and five doses of nitrogen and potassium $\left(\mathrm{D}_{\mathrm{NK}}\right)$, which are presented in Table 1.

Table 1

Representative scheme of the combinations and factors (ECiw - electrical conductivity of irrigation water; $\mathrm{D}_{\mathrm{NK}}$ - nitrogen and potassium doses) used in the experiment

\begin{tabular}{ccccc}
\hline \multirow{2}{*}{ Treatments } & \multicolumn{2}{c}{ Combinations } & \multicolumn{2}{c}{ Factors } \\
\cline { 2 - 5 } & $\mathrm{ECiw}$ & $\mathrm{D}_{\mathrm{NK}}$ & $\left.\mathrm{ECiw}(\mathrm{dS} \mathrm{m})^{-1}\right)$ & $\mathrm{D}_{\mathrm{NK}}(\%)$ \\
\hline 1 & -1 & -1 & 0.98 & 29.08 \\
2 & -1 & 1 & 0.98 & 170.92 \\
3 & 1 & -1 & 3.32 & 29.08 \\
4 & 1 & 1 & 3.32 & 170.92 \\
5 & $-1.41(\alpha)$ & 0 & 0.50 & 100.00 \\
6 & $1.41(\alpha)$ & 0 & 3.80 & 100.00 \\
7 & 0 & $-1.41(\alpha)$ & 100 & 0.00 \\
8 & 0 & $1.41(\alpha)$ & 100 & 200.00 \\
9 & 0 & 0 & 100 & 100.00 \\
\hline
\end{tabular}

The ECiw were obtained by diluting the strongly saline $\left(14.6 \mathrm{dS} \mathrm{m}^{-1}\right)$ dam water with non-saline water $\left(0.5 \mathrm{dS} \mathrm{m}^{-1}\right)$, and the conductivity was monitored with the aid of a portable conductivity meter. Saline levels were chosen based on Oliveira et al. (2015), who observed inhibition in the growth of passion fruit seedlings at ECiw of $1.5 \mathrm{dS} \mathrm{m}^{-1}$.

At 20 days after sowing (DAS), the application of saline water was started, with daily manual irrigation according to the needs of the crop, which was determined based on the drainage lysimetry method proposed by Bernardo, Soares and Mantovani (2006), and this involves applying the volume of evapotranspiration water daily. For this purpose, ten containers were selected; collectors were placed under them to determine the difference between the volume applied and the volume drained from the previous irrigation, and, consequently, the water capacity supported by the container. A leaching fraction of $10 \%$ was applied every 15 days based on the volume of water applied in this period to reduce the accumulation of substrate salts.

The $\mathrm{D}_{\mathrm{NK}}$ used were according to the proposals by Novais, Neves and Barros (1991) for pot, $150 \mathrm{mg}$ $\mathrm{dm}^{-3}$ of K and $300 \mathrm{mg} \mathrm{dm}^{-3}$ of $\mathrm{N}$, which corresponded to the combination of $100 \%$ in this research. The other doses used were: $29.08 \%\left(43.62 \mathrm{mg} \mathrm{dm}^{-3} \mathrm{~K}\right.$ and $\left.87.24 \mathrm{mg} \mathrm{dm}^{-3} \mathrm{~N}\right) ; 170.92 \%\left(256.38 \mathrm{mg} \mathrm{dm}^{-3} \mathrm{~K}\right.$ 
and $\left.512.76 \mathrm{mg} \mathrm{dm}^{-3} \mathrm{~N}\right)$; and $200 \%\left(300 \mathrm{mg} \mathrm{dm}^{-3} \mathrm{~K}\right.$ and $600 \mathrm{mg} \mathrm{dm}^{-3} \mathrm{~N}$ ). To meet the need for nitrogen and potassium, urea and $\mathrm{K}_{2} \mathrm{O}$-based commercial products, respectively, were used. Fertilization with compost was commenced at 20 DAS. In total, seven applications were made weekly in the late afternoon. The products were diluted with distilled water on the day of application.
The passion fruit seedlings were placed in polyethylene bags, with a capacity of $1.15 \mathrm{dm}^{-}$ ${ }^{3}$, filled with substrate composed of $85 \%$ soil, $10 \%$ fine sand, and 5\% tanned cattle manure. The substrate was analyzed for physical and chemical characteristics, such as fertility and salinity, according to the methodologies of Richards (1954) and Empresa Brasileira de Pesquisa Agropecuária [EMBRAPA] (2017) as indicated in Table 2.

Table 2

Physical and chemical composition of the soil substrate components used in the experiment

\begin{tabular}{|c|c|c|c|c|c|}
\hline Physics & Value & Fertility & Value & Salinity & Value \\
\hline Sand $\left(\mathrm{g} \mathrm{kg}^{-1}\right)$ & 639 & $\mathrm{pH}$ in water $(1: 2.5)$ & 7.00 & $\mathrm{pH}$ & 7.30 \\
\hline Silt $\left(\mathrm{g} \mathrm{kg}^{-1}\right)$ & 227 & $\mathrm{P}\left(\mathrm{mg} \mathrm{dm} \mathrm{m}^{-3}\right)$ & 146.32 & $\operatorname{ECse}\left(\mathrm{dS} \mathrm{m}^{-1}\right)$ & 2.73 \\
\hline Clay $\left(\mathrm{g} \mathrm{kg}^{-1}\right)$ & 134 & $\mathrm{~K}^{+}\left(\mathrm{mg} \mathrm{dm}{ }^{-3}\right)$ & 633.29 & $\mathrm{SO}_{4}^{-2}\left(\mathrm{mmol}_{\mathrm{c}} \mathrm{L}^{-1}\right)$ & 1.02 \\
\hline \multirow{9}{*}{ Textural class } & \multirow{9}{*}{ Sandy loam } & $\mathrm{Na}^{+}\left(\mathrm{cmol}_{\mathrm{c}} \mathrm{dm}^{-3}\right)$ & 0.27 & $\mathrm{Ca}^{+2}\left(\mathrm{mmol}_{\mathrm{c}} \mathrm{L}^{-1}\right)$ & 16.00 \\
\hline & & $\mathrm{Al}^{+3}\left(\mathrm{cmol}_{\mathrm{c}} \mathrm{dm}^{-3}\right)$ & 0.00 & $\mathrm{Mg}^{+2}\left(\mathrm{mmol}_{\mathrm{c}} \mathrm{L}^{-1}\right)$ & 16.75 \\
\hline & & $\mathrm{H}^{+}+\mathrm{Al}^{+3}\left(\mathrm{cmol}_{\mathrm{c}} \mathrm{dm}^{-3}\right)$ & 2.84 & $\mathrm{~K}^{+}\left(\mathrm{mmol}_{\mathrm{c}} \mathrm{L}^{-1}\right)$ & 6.90 \\
\hline & & $\mathrm{Ca}^{+2}\left(\mathrm{cmol}_{\mathrm{c}} \mathrm{dm}^{-3}\right)$ & 5.53 & $\mathrm{CO}_{3}^{-2}\left(\mathrm{mmol}_{\mathrm{c}} \mathrm{L}^{-1}\right)$ & 0.00 \\
\hline & & $\mathrm{Mg}^{+2}\left(\mathrm{cmol}_{\mathrm{c}} \mathrm{dm}^{-3}\right)$ & 1.70 & $\mathrm{HCO}_{3}^{-2}\left(\mathrm{mmol}_{\mathrm{c}} \mathrm{L}^{-1}\right)$ & 40.00 \\
\hline & & $\mathrm{SB}\left(\mathrm{cmol}_{\mathrm{c}} \mathrm{dm}^{-3}\right)$ & 9.12 & $\mathrm{Cl}^{-}\left(\mathrm{mmol}_{\mathrm{c}} \mathrm{L}^{-1}\right)$ & 30.00 \\
\hline & & $\operatorname{CEC}\left(\mathrm{cmol}_{\mathrm{c}} \mathrm{dm}^{-3}\right)$ & 11.96 & $\operatorname{SAR}\left(\operatorname{mmol}_{\mathrm{c}} \mathrm{L}^{-1}\right)$ & 0.94 \\
\hline & & $\mathrm{OM}\left(\mathrm{cmol}_{\mathrm{c}} \mathrm{dm}^{-3}\right)$ & 26.69 & $\operatorname{ESP}(\%)$ & 0.13 \\
\hline & & & & Classification & Not Saline \\
\hline
\end{tabular}

Seeds of yellow passion fruit were used for sowing for their high productivity and commercial importance. For the sowing, three seeds were used per polyethylene bag, which was close to the field capacity for sowing passion fruit seeds, until germination was established.

Gas exchange evaluations were performed at 75 DAS using an infrared gas analyzer (IRGA, model LI-6400XT, LI-COR ${ }^{\circledR}$, Nebrasca, USA) with an air flow of $300 \mathrm{~mL} \mathrm{~min}{ }^{-1}$ and a light source of 1200 $\mu \mathrm{mol} \mathrm{m}{ }^{-2} \mathrm{~s}^{-1}$, and measurements were taken between 9:00-10:00 am. The photosynthetic rate (A) ( $\mu \mathrm{mol}$ $\left.\mathrm{CO}_{2} \mathrm{~m}^{-2} \mathrm{~s}^{-1}\right)$, stomatal conductance $(\mathrm{gs})\left(\mathrm{mol} \mathrm{H}_{2} \mathrm{O}\right.$ $\left.\mathrm{m}^{-2} \mathrm{~s}^{-1}\right)$, intercellular $\mathrm{CO}_{2}$ concentration $(\mathrm{Ci})(\mu \mathrm{mol}$
$\left.\mathrm{CO}_{2} \mathrm{~m}^{-2} \mathrm{~s}^{-1}\right)$, and transpiration (E) $\left(\mathrm{mmol} \mathrm{H}_{2} \mathrm{O} \mathrm{m}^{-2}\right.$ $\mathrm{s}^{-1}$ ) were measured. From these, the instantaneous water use efficiency (WUE: A/E), intrinsic water use efficiency (iWUE: A/gs), and instantaneous carboxylation efficiency (iCE: A/Ci) were derived.

Phytomass determination was performed at 75 DAS via destructive evaluation. The plants were collected, washed (roots), and fractionated into leaves, stems, and roots. Subsequently, the materials were stored in previously identified paper bags and placed in an air circulation oven at $65^{\circ} \mathrm{C}$ for 72 hours till a constant weight was achieved. Phytomasses were determined with the aid of a precision scale of $0.01 \mathrm{~g}$ sensitivity. 
The data obtained were subjected to analysis of variance and polynomial regression analysis, using the statistical program R (R Core Team [R], 2017).

\section{Results and Discussion}

The interaction between the evaluated factors, electrical conductivity of the irrigation water (ECiw) and nitrogen and potassium doses $\left(\mathrm{D}_{\mathrm{NK}}\right)$ was significant for intercellular $\mathrm{CO}_{2}$ concentration, transpiration, instantaneous carboxylation efficiency, and stem dry phytomass $(\mathrm{P}<0.05)$. The salinity of the irrigation water affected the following variables in isolation: stomatal conductance, photosynthetic rate, instantaneous and intrinsic efficiency of water use, and leaf and root dry phytomasses $(\mathrm{P}<0.05)$. The nitrogen and potassium doses in isolation affected stomatal conductance, photosynthetic rate, and leaf and root dry phytomasses $(\mathrm{P}<0.05)$ (Table 3$)$.

Table 3

Summary of analysis of variance for stomatal conductance (gs), intercellular $\mathrm{CO} 2$ concentration (Ci), transpiration rate (E), photosynthetic rate (A), instantaneous water use efficiency (WUE), intrinsic water use efficiency (iWUE), instantaneous carboxylation efficiency (iCE), leaf dry phytomass (LDP), stem dry phytomass (SDP), and root dry phytomass (RDP) of yellow passion fruit seedlings subjected to nitrogen and potassium fertilization and irrigation with saline water

\begin{tabular}{cccccccccccc}
\hline Variation & DF & \multicolumn{10}{c}{ Mean Square } \\
\cline { 2 - 11 } source & & gs & Ci & E & A & WUE & iWUE & iCE & LDP & SDP & RDP \\
\hline Blocks & 3 & $0.005^{\text {ns }}$ & $4.70^{\text {ns }}$ & $1.08^{\text {ns }}$ & $4.35^{\text {ns }}$ & $0.07^{\text {ns }}$ & $137.2^{\text {ns }}$ & $4.38 \mathrm{e}-6^{\text {ns }}$ & $0.19^{\text {ns }}$ & $0.08^{\text {ns }}$ & $0.35^{\text {ns }}$ \\
Treatment & 8 & $0.037^{* *}$ & $1416.80^{* *}$ & $5.00^{* *}$ & $13.12^{*}$ & $0.35^{* *}$ & $597.3^{* *}$ & $2.05 \mathrm{e}-4^{* *}$ & $2.43^{* *}$ & $5.75^{* *}$ & $3.19^{* *}$ \\
\hline Doses NK(L) & 1 & $0.001^{\text {ns }}$ & $17.02^{* *}$ & $1.54^{* *}$ & $2.93^{* *}$ & $0.07^{\text {ns }}$ & $8.50^{\text {ns }}$ & $0.009^{* *}$ & $1.01^{*}$ & $1.73^{* *}$ & $1.98^{* *}$ \\
Doses NK (Q) & 1 & $0.167^{* *}$ & $8.47^{\text {ns }}$ & $0.18^{\text {ns }}$ & $2.65^{*}$ & $0.09^{\text {ns }}$ & $6.00^{\text {ns }}$ & $0.014^{* *}$ & $1.34^{* *}$ & $2.25^{* *}$ & $1.30^{* *}$ \\
ECiw (L) & 1 & $0.120^{* *}$ & $38.39^{* *}$ & $1.11^{*}$ & $1.40^{\text {ns }}$ & $0.67^{* *}$ & $23.28^{* *}$ & $0.001^{\text {ns }}$ & $1.05^{* *}$ & $0.32^{\text {ns }}$ & $0.07^{\text {ns }}$ \\
ECiw (Q) & 1 & $0.062^{\text {ns }}$ & $14.30^{*}$ & $1.53^{* *}$ & $2.78^{*}$ & $0.22^{*}$ & $8.15^{\text {ns }}$ & $0.012^{* *}$ & $0.47^{\text {ns }}$ & $1.28^{* *}$ & $1.13^{* *}$ \\
$\begin{array}{c}\text { Doses NK (L) } \\
\text { x ECiw (L) }\end{array}$ & 1 & $0.015^{\text {ns }}$ & $3.50^{*}$ & $0.33^{*}$ & $0.75^{\text {ns }}$ & $0.01^{\text {ns }}$ & $0.27^{\text {ns }}$ & $0.002^{* *}$ & $0.09^{\text {ns }}$ & $0.20^{*}$ & $0.02^{\text {ns }}$ \\
\hline CV & & 18.90 & 3.10 & 9.30 & 11.60 & 9.50 & 15.90 & 9.80 & 15.00 & 14.10 & 13.50 \\
\hline
\end{tabular}

The gs reduced linearly with the increase in saline levels with a value of $0.271 \mathrm{~mol} \mathrm{H}_{2} \mathrm{O} \mathrm{m} \mathrm{m}^{-2}$ $\mathrm{s}^{-1}$ at ECiw of $3.80 \mathrm{dS} \mathrm{m}^{-1}$, a reduction of $36.7 \%$ in comparison with the control treatment (Figure $1 \mathrm{~A})$. For A, there were reductions when compared to the control treatment up to ECiw of $2.62 \mathrm{dS} \mathrm{m}^{-1}$, with values varying between 12.95 and $16.82 \mu \mathrm{mol}$ $\mathrm{CO}_{2} \mathrm{~m}^{-2} \mathrm{~s}^{-1}$ (Figure 1B). The WUE increased up to ECiw of $2.20 \mathrm{dS} \mathrm{m}^{-1}$ (Figure 1C). The iWUE, on the other hand, increased linearly with values of 9.01 and 22.36 at ECiw of $0.50 \mathrm{dS} \mathrm{m}^{-1}$ and $3.80 \mathrm{dS} \mathrm{m}^{-1}$, respectively (Figure 1D).

The reduction in stomatal conductance occurred due to the decrease in the soil osmotic potential, making it difficult for plants to absorb water. As a way of adapting to water stress, there is increased stomatal resistance resulting in decreased water loss through the transpiration process, and consequently, decreased $\mathrm{CO}_{2}$ entry into the cells, thereby inducing a lower photosynthetic rate (Freire et al., 2014). The increase in the instantaneous and intrinsic efficiency of water use allows researchers to deduce that passion fruit plants have a certain tolerance to saline stress, managing to maintain carbon assimilation to a certain extent. However, reductions in these variables is an indication that physiological activity is being compromised (L. A. Silva et al., 2014). Similar results were obtained by E. M. Silva et al. (2018) in soursop plants (Annona muricata L.). 

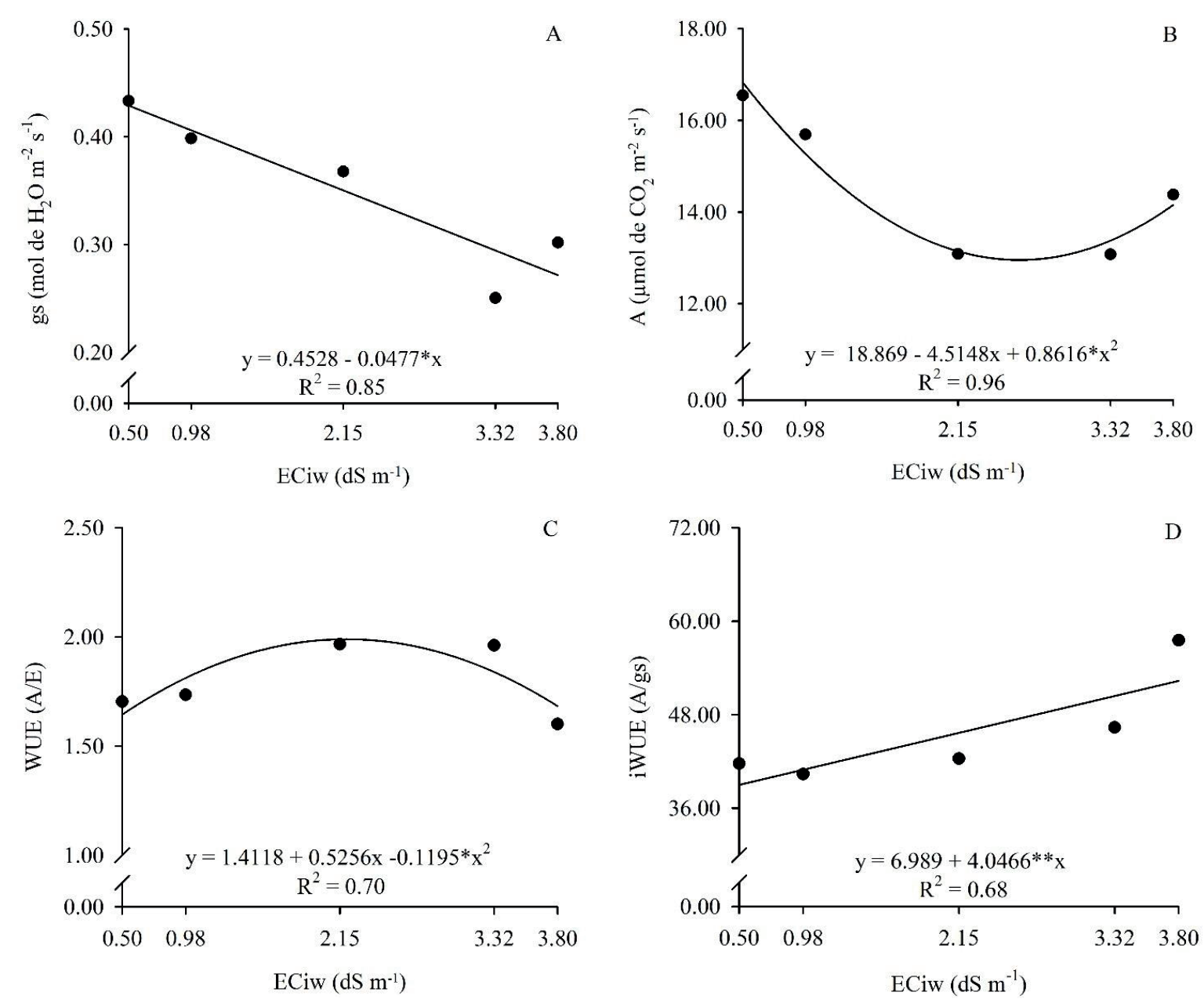

Figure 1. Stomatal conductance - gs (A), photosynthetic rate - A (B), instantaneous water use efficiency WUE (C), and intrinsic water use efficiency iWUE (D) of yellow passion fruit seedlings under saline stress.

Regarding the effects of $\mathrm{D}_{\mathrm{NK}}$, gs was positively influenced up to a dose of $110 \%$ (Figure 2A). The photosynthetic rate (A) increased up to a dose of $104.3 \%$ with a value of $15.51 \mu \mathrm{mol} \mathrm{CO} \mathrm{Cm}^{-2} \mathrm{~s}^{-1}$ (Figure 2B). This result can be attributed to the fact that fertilization with these nutrients favors biosynthesis of photosynthetic components, such as the rubisco enzyme and chlorophyll molecules, inducing stomatal opening due to the greater demand for $\mathrm{CO}_{2}$ (Freitas, Almeida, Lago, Souza, \& Souza, 2012).

For $\mathrm{Ci}$ and $\mathrm{E}$, fertilization with $\mathrm{D}_{\mathrm{NK}}$ of $69.7 \%$ and $96.3 \%$ attenuated the deleterious effects of salinity up to ECiw of 2.01 and $1.65 \mathrm{dS} \mathrm{m}^{-1}$, respectively
(Figures 3A and 3B). The highest iCE was found at a dose of $198.7 \%$ and salinity of $0.50 \mathrm{dS} \mathrm{m}^{-1}$ (Figure 3C). The results observed for $\mathrm{Ci}$ and $\mathrm{E}$ showed that, in these conditions, the stoma opening and closing mechanism did not restrict the assimilation of $\mathrm{CO}_{2}$ and transpiration rate. In addition, increase in nitrogen supply promotes greater accumulation of organic compounds and plays an important role in osmotic balance (Feijão, Silva, Marques, Prisco, \& Gomes, 2011; Nobre, Gheyi, Correia, Soares, \& Andrade, 2010). Potassium, on the other hand, acts in several biological processes in plants, such as enzyme activation, respiration, and improvement of water balance (Mendes, Paula, Scarpinatti, \& Paula, 2013; Prazeres et al., 2015). 

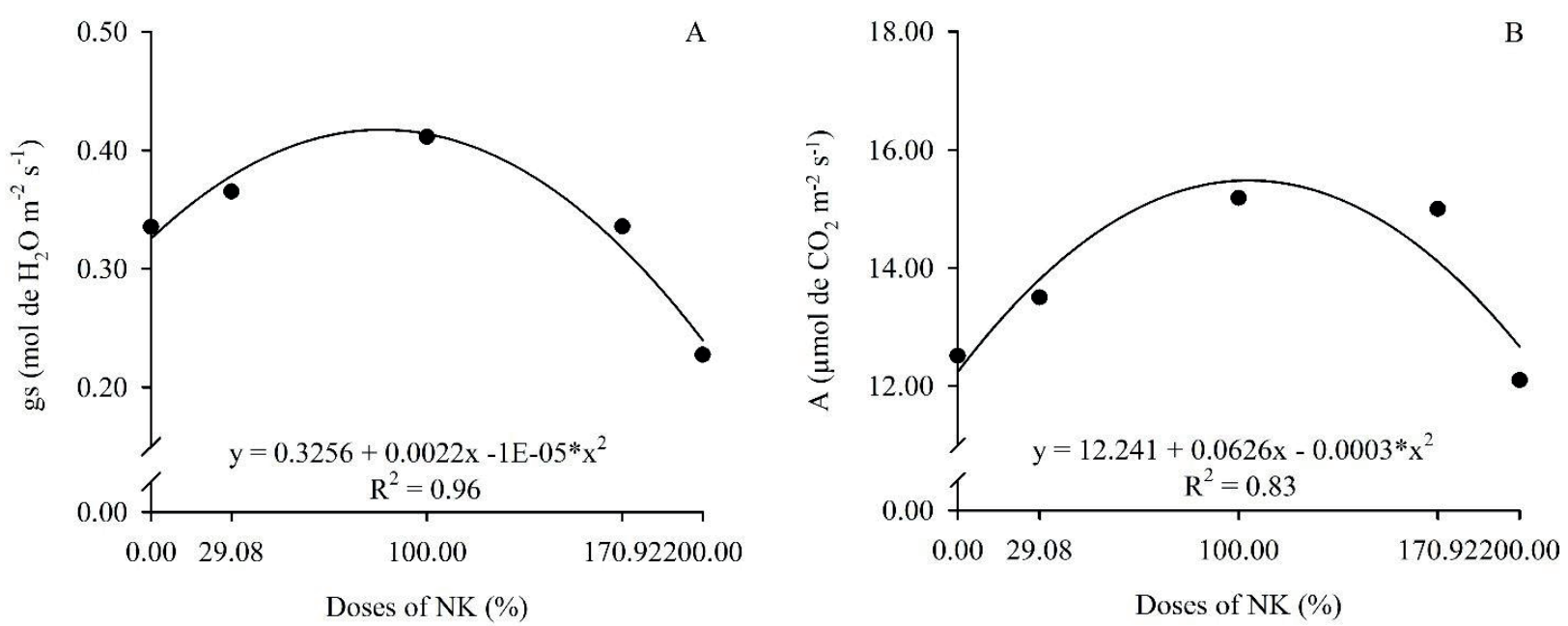

Figure 2. Stomatal conductance - gs (A) and photosynthetic rate - A (B) of yellow passion fruit seedlings under nitrogen and potassium doses.
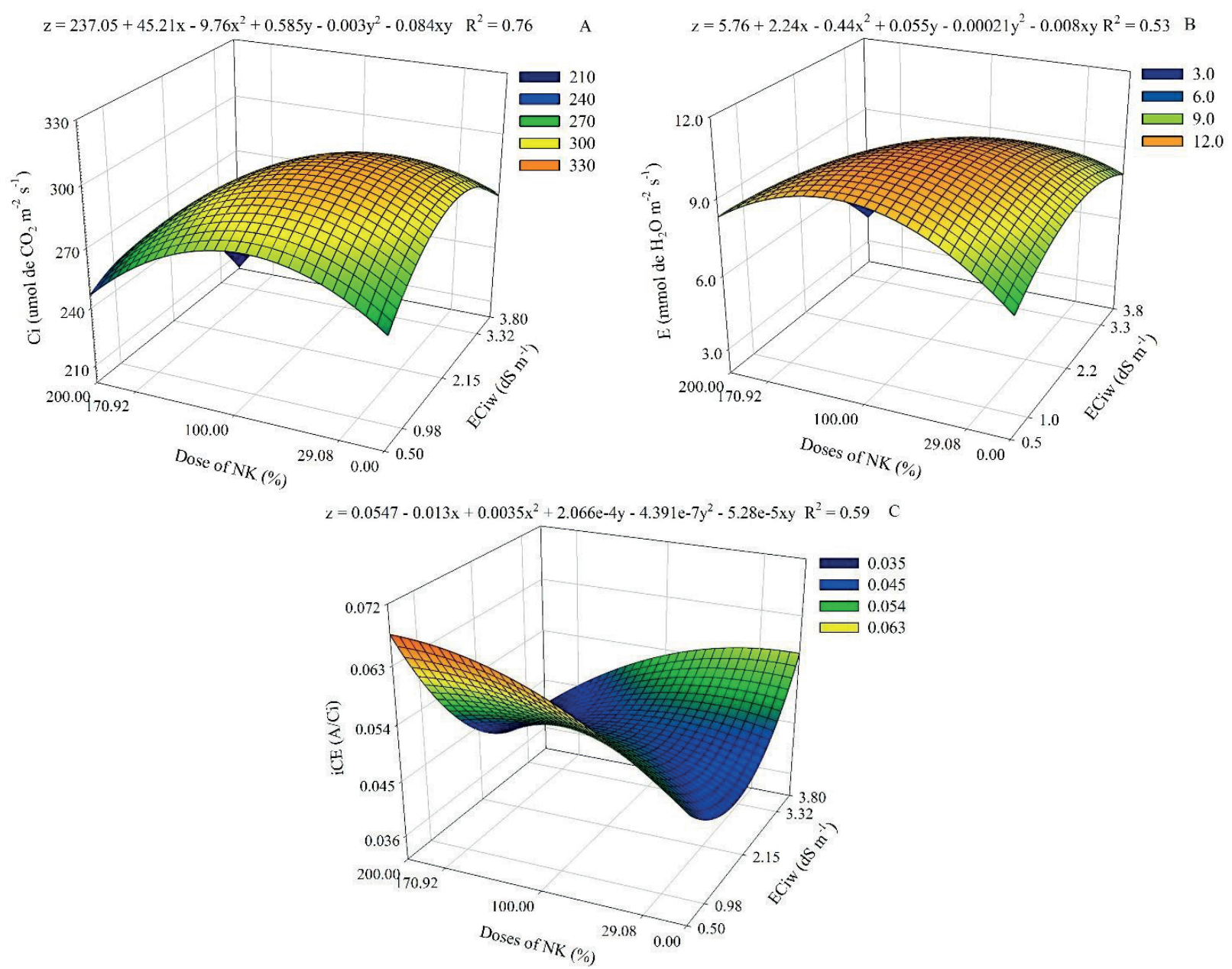

Figure 3. Intercellular $\mathrm{CO}_{2}$ concentration - $\mathrm{Ci}(\mathrm{A})$, transpiration rate - $\mathrm{E}(\mathrm{B})$, and instantaneous carboxylation efficiency - iCE (C) of yellow passion fruit seedlings under saline stress and nitrogen and potassium doses. 
However, the highest iCE observed at salinity of $0.5 \mathrm{dS} \mathrm{m}^{-1}$ is an indication that the damage to the photosynthetic apparatus occured due to stomatic and non-stomatic factors, through biochemical changes affecting the energy supply and rubisco enzyme activity (Sá et al., 2019). In cowpea (Vigna unguiculata L.) and castor bean (Ricinus communis L.) plants, the interaction between nitrogen fertilization and irrigation water salinity did not influence the gas exchange of these species (Furtado, Soares, Sousa, Andrade, \& Guerra, 2013; Soares, Lima, Nobre, Gheyi, \& Pereira, 2013), and this is contrary to the result obtained in the present study. For potassium, the optimal dose of this nutrient depends on the soil salt level in the root zone and the source used in fertilization (Prazeres et al., 2015).

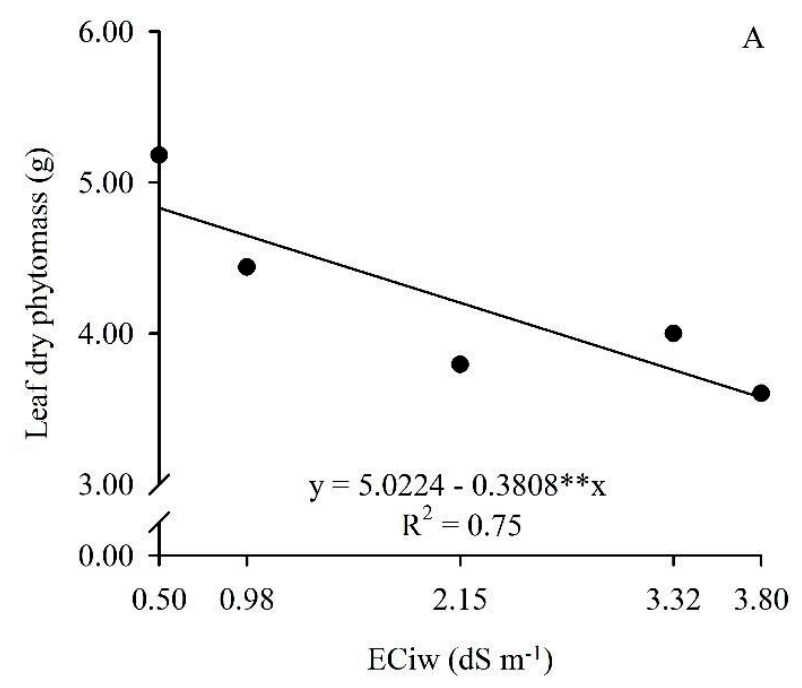

Figure 4. Leaf dry phytomass (A) and root dry phytomass

Regarding the isolated effects of fertilization with nitrogen and potassium, the $\mathrm{D}_{\mathrm{NK}}$ of $145 \%$ and $130.5 \%$ provided the best results for leaf and root dry phytomasses, with values of 4.45 and $4.14 \mathrm{~g}$, respectively, (Figures 5A and 5B). This increase can be explained by higher photosynthetic rates induced by the nitrogen and potassium fertilizer and, consequently, greater biomass accumulation (Marschner, 2012). Similar results were found by
The leaf dry phytomass reduced linearly with increase in the ECiw, with values of 4.83 and 3.57 $\mathrm{g}$ at salinities of 0.5 and $3.8 \mathrm{dS} \mathrm{m}^{-1}$, respectively, representing a reduction of $26.1 \%$ (Figure $4 \mathrm{~A}$ ). The root dry phytomass was reduced at ECiw of $3 \mathrm{dS} \mathrm{m}^{-1}$, with a value of $2.45 \mathrm{~g}$ (Figure 4B). These decreases occurred due to the large amount of soluble salts in the root system, which reduced the osmotic potential of the soil, leading to plant growth inhibition due to the resulting water deficiency (Bezerra, Pereira, Silva, \& Raposo, 2016). These same authors found results similar to those of the present study in passion fruit genotypes under salinity conditions. A similar result was also observed by Costa, Fernandes, Barreto, Oliveira, \& Santos (2012) in watermelon (Citrulus lanatus L.) plants under the application of saline water up to $5 \mathrm{dS} \mathrm{m}^{-1}$.

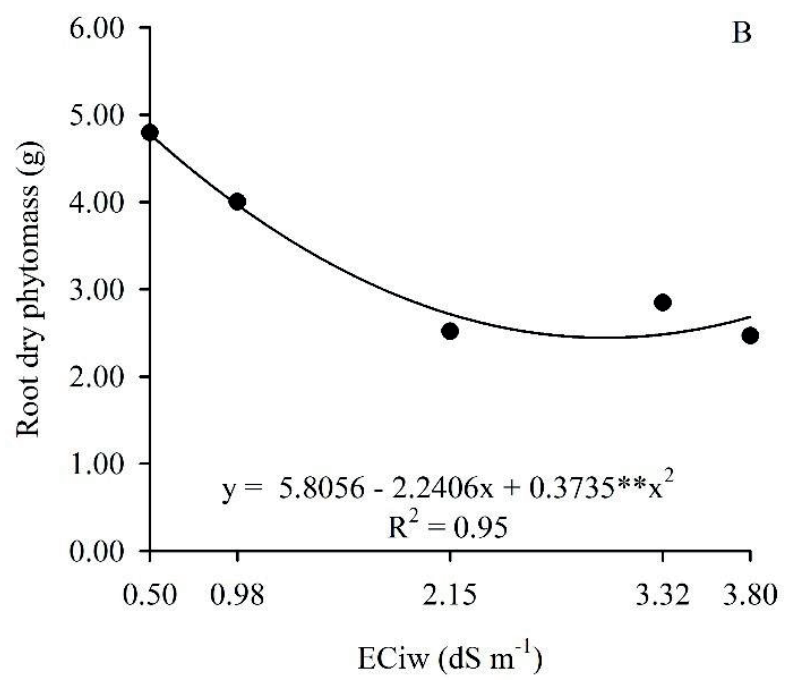

(B) of yellow passion fruit seedlings under saline stress.

Souza et al. (2007) and Bezerra, Pereira, Bezerra, Cavalcante, \& Medeiros (2014) in yellow passion fruit seedlings.

The stem dry phytomass was higher in the $\mathrm{D}_{\mathrm{NK}}$ of $199.7 \%$ and salinity of $0.5 \mathrm{dS} \mathrm{m} \mathrm{m}^{-1}$, with a value of $7.32 \mathrm{~g}$ (Figure 6). These values demonstrate that the application of nitrogen and potassium up to the aforementioned dose favors a greater supply of 
photoassimilates leading to an increase in biomass production (Andrade, Pereira, Fernandes, Queiroga, \& Queiroga, 2011). Consistent with the results of the present study, Lima, Nobre, Gheyi, Soares and Silva (2014) also reported positive effects of nitrogen fertilization on castor bean plants under saline stress, obtaining the best results when the plants were subjected to $2.4 \mathrm{dS} \mathrm{m}^{-1}$ of ECiw and a dose of $150 \mathrm{mg} \mathrm{kg}^{-1}$ of $\mathrm{N}$. In contrast to these reports, Oliveira et al. (2010) reported that salinity linearly reduced the dry matter of sunflower (Helianthus annus L.) regardless of the nitrogen source used.
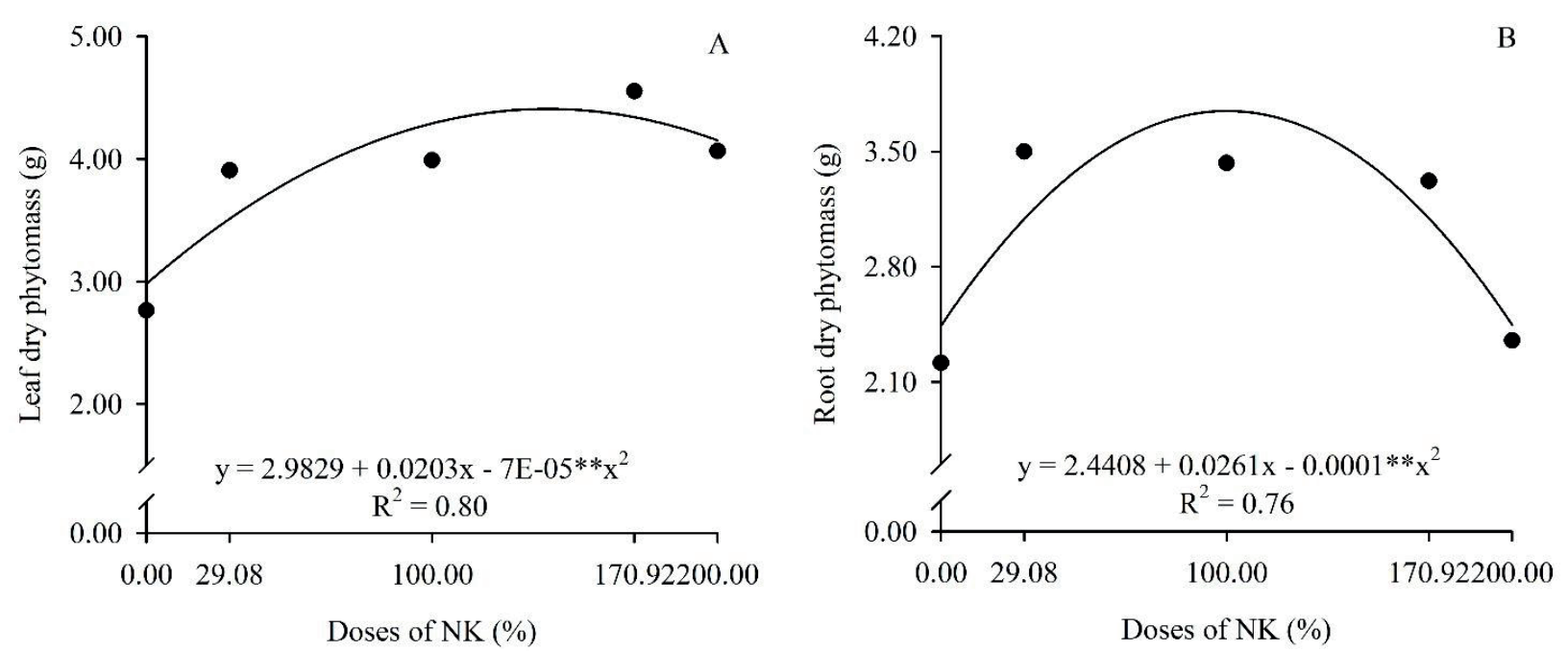

Figure 5. Leaf dry phytomass (A) and root dry phytomass (B) of yellow passion fruit seedlings under nitrogen and potassium doses.

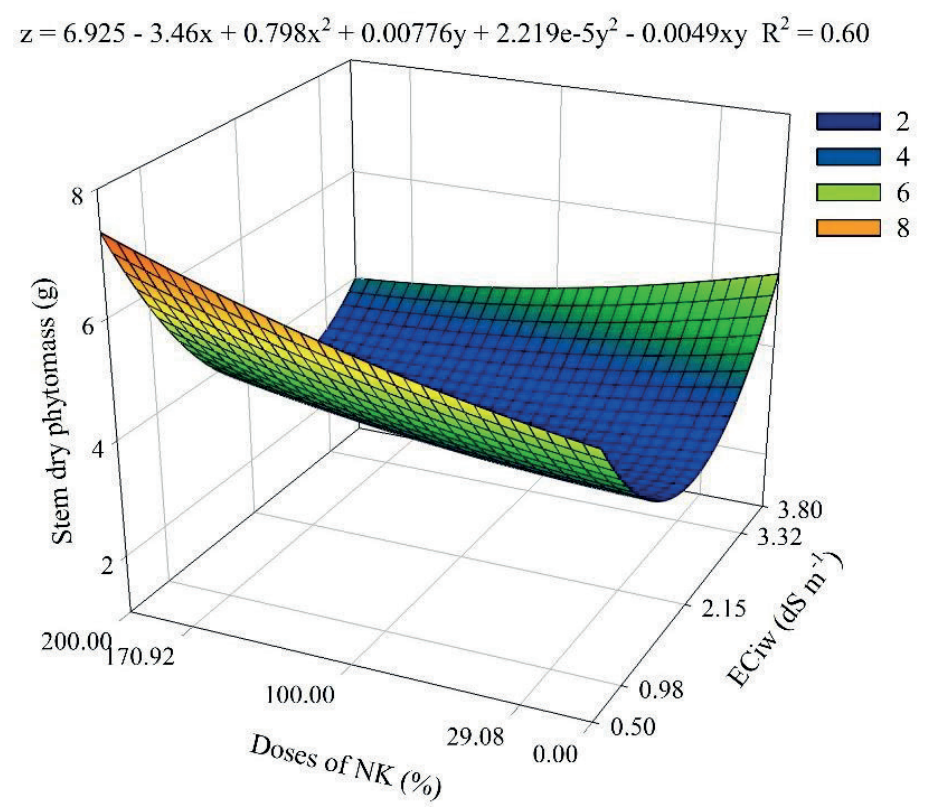

Figure 6. Stem dry phytomass of yellow passion fruit seedlings under saline stress and doses of nitrogen and potassium. 


\section{Conclusions}

The increase in the electrical conductivity of irrigation water has negative effects on the morphophysiological characteristics of the yellow passion fruit.

The application of nitrogen and potassium positively influenced photosynthesis and leaf and root dry phytomasses.

The application of nitrogen and potassium increases the intercellular $\mathrm{CO}_{2}$ concentration and transpiration rate of yellow passion fruit seedlings under saline stress.

\section{Acknowledgment}

The authors would like to thank Coordenação de Aperfeiçoamento de Pessoal de Nível Superior (CAPES) and the Conselho Nacional de Desenvolvimento Científico e Tecnológico $(\mathrm{CNPq})$ for financial assistance in conducting the experiments.

\section{References}

Almeida, H. J., Pancelli, M. A., Prado, R. M., Cavalcante, V. S., \& Cruz, F. J. R. (2015). Effect of potassium on nutritional status and productivity of peanuts in succession with sugarcane. Journal of Soil Science and Plant Nutrition, 15(1), 1-10. doi: 10.4067/ S0718-95162015005000001

Alvares, C. A., Stape, J. L., Sentelhas, P. C., Gonçalves, J. L. M., \& Sparovek, G. (2013). Köppen's climate classification map for Brazil. Meteorologische Zeitschrift, 22(6), 711-728. doi: 10.1127/0941-2948/ 2013/0507

Andrade, W. P., Jr., Pereira, F. H. F., Fernandes, O. B., Queiroga, R. C. F., \& Queiroga, F. M. (2011). Efeito do nitrato de potássio na redução do estresse salino no meloeiro. Revista Caatinga, 24(3), 110-119.

Araújo, E. B. G., Sá, F. V. S., Oliveira, F. A., Souto, L. S., Paiva, E. P., Silva, M. K. N.,... Brito, M. E. B. (2016). Crescimento inicial e tolerância de cultivares de meloeiro à salinidade da água. Revista Ambiente e Água, 11(2), 462-471. doi: 10.4136/1980-993X
Bernardo, S., Soares, A. A., \& Mantovani, E. C. (2006). Manual de irrigação. (8a ed.). Viçosa, MG: UFV.

Bezerra, J. D., Pereira, W. E., Silva, J. M., \& Raposo, R. W. C. (2016). Crescimento de dois genótipos de maracujazeiro-amarelo sob condições salinas. Revista Ceres, 63(4), 502-508. doi: 10.1590/0034737X 201663040010

Bezerra, M. A. F., Cavalcante, L. F., Bezerra, F. T. C., Silva, A. R., Oliveira, F. F., \& Medeiros, S. A. S. (2019). Saline water, pit coating and calcium fertilization on chlorophyll, fluorescence, gas exchange and production in passion fruit. Journal of Agricultural Science, 11(2), 319-329. doi: 10.5539/ jas.v11 n2p319

Bezerra, M. A. F., Pereira, W. E., Bezerra, F. T. C., Cavalcante, L. F., \& Medeiros, S. A. S. (2014). Água salina e nitrogênio na emergência e biomassa de mudas de maracujazeiro amarelo. Revista Agropecuária Técnica, 35(1), 150-160. doi: 10.25066/agrotec.v35i1.19920

Cavalcante, L. F., Dias, T. J., Nascimento, R., \& Freire, J. L. O. (2011). Clorofila e carotenoides em maracujazeiro-amarelo irrigado com águas salinas no solo com biofertilizante bovino. Revista Brasileira de Fruticultura, 33(1), 699-705. doi: 10.1590/S0100-29452011000500098

Costa, F. G. B., Fernandes, M. B., Barreto, H. B. F., Oliveira, M. A. F., \& Santos, W. O. (2012). Crescimento da melancia e monitoramento da salinidade do solo com TDR sob irrigação com água de diferentes salinidades. Irriga , 17(3), 327-336. doi: 10.15809/irriga.2012v17n3p327

Empresa Brasileira de Pesquisa Agropecuária (2017). Manual de métodos de análise de solo. Manual de análises químicas de solos, plantas e fertilizantes. Brasília, DF: EMBRAPA.

Feijão, A. R., Silva, J. C. B., Marques, E. C., Prisco, J. T., \& Gomes, E., Fo. (2011). Efeito da nutrição de nitrato na tolerância de plantas de sorgo sudão à salinidade. Revista Ciência Agronômica, 42(3), 675683. doi: 10.1590/S1806-66902011000300014

Figueiredo, F. R. A., Hafle, O. M., Rodrigues, M. H. B. S., Pereira, E. B., Jr., \& Delfino, F. I. (2015). Produtividade e qualidade dos frutos do maracujazeiro-amarelo sob diferentes formas de condução das plantas. Agropecuária Científica no Semiárido, 11(4), 23-32. doi: 10.30969/acsa. v11i4.672 
Freire, J. L. O., Dias, T. J., Cavalcante, L. F., Fernandes, P. D., \& Lima, A. J., Neto. (2014). Rendimento quântico e trocas gasosas em maracujazeiro amarelo sob salinidade hídrica, biofertilização e cobertura morta. Revista Ciência Agronômica, 45(1), 82-91. doi: 10.1590/S1806-66902014000100011

Freitas, J. C. O., Almeida, A. A. F., Lago, M. F., Souza, M. M., \& Souza, J. O., Jr. (2012). Características morfofisiológicas de plantas clonais de Passiflora alata crescidas em diferentes doses de nitrogênio e níveis de sombreamento. Revista Brasileira de Fruticultura, 34(3), 859-872. doi: 10.1590/S010029452012000300028

Furtado, G. F., Soares, L. A. A., Sousa, J. R. M., Andrade, E. M. G., \& Guerra, H. O. C. (2013). Alterações fisiológicas em feijão-caupi irrigado com água salina e adubação nitrogenada. Revista Verde de Agroecologia e Desenvolvimento Sustentável, 8(3), 175-181.

Lima, G. S., Nobre, R. G., Gheyi, H. R., Soares, L. A. A., \& Silva, A. O. (2014). Crescimento e componentes de produção da mamoneira sob estresse salino e adubação nitrogenada. Engenharia Agrícola, 34(5), 854-866. doi: 10.1590/S0100-69162014000500005

Marschner, P. (2012). Mineral nutrition of higher plants (3a ed.). San Diego: USA, Elsevier ${ }^{\circledR}$.

Mateus, N. B., Barbin, D., \& Conagin, A. (2001). Viabilidade de uso do delineamento composto central. Acta Scientiarum, 23(6), 1537-1546. doi: 10.4024/actascitechnol.v23i0.2795

Mendes, H. S. J., Paula, N. F., Scarpinatti, E. A. \& Paula, R. C. (2013). Respostas fisiológicas de genótipos de Eucalyptus grandis x E. urophylla à disponibilidade hídrica e adubação potássica. Revista Cerne, 19(4), 603-611. doi: 10.1590/S0104-77602013000400010

Nobre, R. G., Gheyi, H. R., Correia, K. G., Soares, F. A. L., \& Andrade, L. O. (2010). Crescimento e floração do girassol sob estresse salino e adubação nitrogenada. Revista Ciência Agronômica, 41(3), 358-365. doi: 10.1590/S1806-66902010000300006

Novais, R. F., Neves J. C. L., \& Barros, N. F. (1991). Ensaio em ambiente controlado. In A. J. Oliveira (Ed.), Métodos de pesquisa em fertilidade do solo. Brasília, DF: EMBRAPA-SEA.

Oliveira, F. A., Lopes, M. Â. C., Sá, F. V. S., Nobre, R. G., Moreira, R. C. L., Silva, L. A., \& Paiva, E. P. (2015). Interação salinidade da água de irrigação e substratos na produção de mudas de maracujazeiro amarelo. Comunicata Scientiae, 6(4), 471-478. doi: 10.14295/CS.v6i4.982
Oliveira, F. A., Medeiros, J. F., Alves, R. C., Linhares, P. S. F., Medeiros, A. M. A., \& Oliveira, M. K. T. (2014). Interação entre a salinidade da água de irrigação e adubação nitrogenada na cultura da berinjela. Revista Brasileira de Engenharia Agrícola e Ambiental, 18(5), 480-486. doi: 10.1590/S141543662014000500003

Oliveira, F. A., Oliveira, F. R. A., Campos, M. S., Oliveira, M. K. T., Medeiros, J. F., \& Silva, O. M. P. (2010). Interação entre salinidade e fontes de nitrogênio no desenvolvimento inicial da cultura do girassol. Revista Brasileira de Ciências Agrárias, 5(4), 479484. doi: 10.5039/agraria.v5i4a806.

Prazeres, S. S., Lacerda, C. F., Barbosa, F. E. L., Amorim, A. V., Araújo, I. C. S., \& Cavalcante, L. F. (2015). Crescimento e trocas gasosas de plantas de feijão-caupi sob irrigação salina e doses de potássio.RevistaAgro@mbiente, 9(2), 111-118. doi: 10.18227/1982-8470ragro.v9i2.2161

R Core Team (2017). R: A language and environment for statistical computing. Vienna, Austria: R Foundation for Statistical Computing.

Richards, L. A. (1954). Diagnosis and improvement of saline and alkaline soils. (Agriculture, 60). Washington: United States Salinity Laboratory Staff.

Sá, F. V. S., Gheyi, H. R., Lima, G. S., Paiva, E. P., Silva, L. A., Moreira, R. C. L.,... Dias, A. S. (2019). Ecophysiology os west indian cherry irrigated with saline water under phosphorus and nitrogen doses. Bioscience Journal, 35(1), 211-221. doi: 10.14393/ BJ-v35n1a2019-41742

Silva, E. M., Lima, G. S., Gheyi, H. R., Nobre, R. G., Sá, F. V. S., \& Souza, L. P. (2018). Growth and gas exchanges in soursop under irrigation with saline water and nitrogen sources. Revista Brasileira de Engenharia Agrícola e Ambiental, 22(11), 776-781. doi: 10.1590/1807-1929/agriambi.v22n11p776-781

Silva, L. A., Brito, M. E. B., Sá, F. V. S., Moreira, R. C. L., Soares, W. S., Fo ., \& Fernandes, P. D. (2014). Mecanismos fisiológicos em híbridos de citros sob estresse salino em cultivo hidropônico. Revista Brasileira de Engenharia Agrícola e Ambiental, 18(suppl), S1-S7. doi: 10.1590/1807-1929/agriambi. v18nsupps1-s7

Soares, L. A. A., Lima, G. S., Nobre, R. G., Gheyi, H. R., \& Pereira, F. H. F. (2013). Fisiologia e acúmulo de fitomassa pela mamoneira submetida a estresse salino e adubação nitrogenada. Revista Verde Agroecologia e Desenvolvimento Sustentável, 8(1), 247-256. 
Souza, H. A., Mendonça, V., Abreu, N. A. A., Teixeira, G. A., Gurgel, R. L. S., \& Ramos, J. D. (2007). Adubação nitrogenada e substratos na produção de mudas de maracujazeiro doce. Ciência e Agrotecnologia, 31(3), 599-604. doi: 10.1590/S1413-70542007000300001

Taiz, L., Zeiger, E., Moller, I. M., \& Murphy, A. (2017). Fisiologia e desenvolvimento vegetal (6a ed.). Porto Alegre: Artmed. 